\title{
Evaluation of some oxidative-stress and antioxidant markers in goats during estrous cycle under Egyptian environmental conditions
}

Fatma Edrees Ibrahim Teama $^{1^{*}}$

\author{
${ }^{1}$ Atomic Energy Authority, Nuclear Research Center, Department of Biological Applications, Inshas, Cairo, Egypt.
}

\begin{abstract}
The objective of this study was to explore the impact of thermal stress on hormonal level and antioxidant activity in goats during various phases of the estrous cycle in the Egyptian summer. Forty cycling does were allocated to two groups (20 animals each) divided by season (mild/hot). Daily meteorological, rectal temperature, and respiratory rate data were recorded in the two seasons. The estrous cycle of the goats was synchronized by two intramuscular injections of $5 \mathrm{mg}$ of prostaglandin F2 $\alpha$ (PGF2 $\alpha$ ) at 11-day intervals. Blood samples were collected every two days and the levels of total antioxidant, malondialdehyde, and $\beta$-carotene were estimated. Total protein, albumin, cholesterol, triglycerides, progesterone, and thyroxine $\left(\mathrm{T}_{4}\right)$ hormones were additionally measured in the serum of the collected samples. Under hot circumstances, both rectal temperature and respiratory rate increased considerably, with significant variation during the different stages of the estrous cycle. On the other hand, serum level of total protein, albumin, cholesterol, and triglycerides reduced significantly in animals in the hot environment, particularly during the luteal period of the estrous cycle (IV). During the Egyptian hot summer, the serum level of progesterone and $\mathrm{T}_{4}$ hormones declined in phases II and IV of the estrous cycle for progesterone and $\mathrm{T}_{4}$, respectively. Moreover, the serum content of all oxidative stress markers tested (total antioxidant, $\beta$-carotene, and malondialdehyde) decreased considerably, especially in estrous cycle phase II in the hot environment. The Egyptian environmental conditions have detrimental effects on some antioxidant agents and some biochemical parameters throughout the estrous cycle of goats.
\end{abstract}

Key Words: $\beta$-carotene, hot season, malondialdehyde, thermal stress, total antioxidants

\section{Introduction}

Oxidative stress is an imbalance between radicalgenerating and radical-scavenging activities resulting from increased production of pro-oxidants and/or a decrease in antioxidant defense (Bernabucci et al., 2002). Reactive oxygen metabolites (ROM) are free radicals of an organism that constitute approximately $1-2 \%$ of the body and have essential functions such as protein phosphorylation, cell maturation, apoptosis, oocyte maturation, steroidogenesis, cell immunity, ovulation, implantation, blastocyst formation, luteolysis, acrosome reactions, fertilization, and luteal maintenance during pregnancy (Celi et al., 2012). However, their levels increase at certain pathological conditions, which can also cause damage of biological macromolecules and disrupt typical metabolism and physiology (Trevisan

Received: December 15, 2016

Accepted: November 20, 2017

*Corresponding author: fatema58us@yahoo.com

Copyright (C) 2018 Sociedade Brasileira de Zootecnia. This is an Open Access article distributed under the terms of the Creative Commons Attribution License (http://creativecommons.org/licenses/by/4.0/), which permits unrestricted use, distribution, and reproduction in any medium, provided the original work is properly cited. et al., 2001). During heat stress, particularly in tropical regions, rapid production of free radicals and ROS and/or a reduced antioxidant mechanism result in the production of oxidative stress, which affects numerous biological features of livestock (Sordillo and Aitken, 2009; Celi, 2011). The Egyptian summer is exceptionally sweltering, with recorded temperatures between $30-40{ }^{\circ} \mathrm{C}$ around noon, high humidity near coastal regions, and extreme dryness in the desert (Marai et al., 2007). This climatic circumstance has a diminishing impact on both productive and reproductive efficiency of livestock (Jordan, 2003).

Goats are one of the oldest domesticated species, considered living species greatly adaptable to the hot and arid regions of the world (Hooda and Upadhyay, 2014). As a result of heat stress, hyperthermia will develop, negatively influencing the physiological performance of livestock, especially throughout the estrous cycle, and having economic impacts on the livestock industry (Monty and Wolff, 1974; Wolff and Monty, 1974). The estrous cycle of a female goat lasts about 21 days. The cycle is characterized by four phases or periods: estrus or heat period (phase I, 12-48 h); metestrus period (phase II, two days); diestrus period (phase III, 19 days); and proestrus period (phase IV, three days) (Jarosz et al., 1971). The estrous 
cycle is associated with various metabolic and hormonal variations in farm animals (Browne et al., 2008). The relationship between production of reactive oxygen species (ROS) in heat-stressed animals during the estrous cycle and their impact on the performance of these animals is still deficiently considered. Consequently, better understanding of such effects in heat-stressed farm animals can help to improve the overall performance of these animals in a hot environment regarding physiology and reproduction. For instance, oxidative stress can be reduced by providing antioxidant nutrients as well as limiting the impacts of substances that create ROS (Miller et al., 1993). On these bases, the present study was designed to investigate the impact of heat stress on the level of some physiological and biochemical parameters, including antioxidant activity, in goats during the estrous cycle under Egyptian summer conditions.

\section{Material and Methods}

Forty healthy native non-lactating female crossbred (Zaraibi $\times$ Baladi) goats, clinically free of external and internal parasites, were used. Does aged 2-3 years, with a body weight of $34 \pm 2.4 \mathrm{~kg}$, were selected according to farm reproduction records located in sharqya government (Inshas area). Research on animals was conducted according to the local ethics committee on animal use (133). All does were kept in semi-open pens throughout the experimental period and fed a basal diet with a concentrate feed mixture according to NRC (2007) requirements for goats. Fresh drinking water was given daily ad libitum. Does were allotted to two groups according to ambient temperature (mild and hot) during the estrous cycle, each containing twenty does. The animals were housed in a semi-roofed yard and kept under similar feeding and management conditions during the two periods.

Prior to the experiment, animals were fed for two weeks as an adaptation period. To synchronize their estrous cycle, all animals received two intramuscular injections of $5 \mathrm{mg}$ of prostaglandin F2 $\alpha$ (PGF2 $\alpha$ ) (lutalyse) at 11-day intervals. To recognize the estrous status, the rectal temperature was recorded routinely and the indications of estrous were observed likewise. These signs included consistent vocalization, loss of appetite, redness and swelling around the vulva, and a thin mucus discharge from the vulva. The experimental work was carried out during the estrous cycle under two climatic conditions of the Egyptian environment: the mild season (from February to March 2014) and the hot season (from July to August 2014).
Ambient temperature and relative humidity were obtained daily from the meteorological station of the farm during the entire experimental period. The average temperature, humidity, and temperature-humidity index (THI) were determined as described by LPHSI (1990) and modified by Marai et al. (2007). After the temperature was measured $\left({ }^{\circ} \mathrm{C}\right)$, THI was calculated as follows: $\mathrm{THI}=\mathrm{db}^{\circ} \mathrm{C}$ $-\left\{(0.31-0.31 \mathrm{RH})\left(\mathrm{db}^{\circ} \mathrm{C}-14.4\right)\right\}$, in which $\mathrm{db}^{\circ} \mathrm{C}$ is the dry bulb temperature $\left({ }^{\circ} \mathrm{C}\right)$ and $\mathrm{RH}$ is the relative humidity (RH \%)/100. The animals were under the experimental conditions during half of the day (about $8 \mathrm{~h} /$ day).

Rectal temperature (RT) of each goat was measured daily using a digital thermometer, while respiratory rate $(R R)$ was obtained daily as the number of respiration movements per minute (breaths $/ \mathrm{min})$. Blood samples $(10 \mathrm{~mL})$ from each animal were collected from the jugular vein every two days during one estrous cycle from late July to August (hot condition) and from February to March (mild condition).

Blood samples were collected using non-anticoagulant tubes, which were centrifuged at $3000 \times g$ for $20 \mathrm{~min}$ at $4{ }^{\circ} \mathrm{C}$. Separated-serum samples were stored at $-20{ }^{\circ} \mathrm{C}$ until the assay. Total antioxidant oxidant capacity was determined according to the method of Koracevic et al (2001), using a kit from BioDiagnostics (BioDiagnostics, Dokki, Egypt), in which a Fe-EDTA complex reacts with hydrogen peroxide by a fenton-type reaction, leading to the formation of hydroxyl radicals that degrade benzoate, followed by release of thiobarbituric acid reactive substances.

The antioxidants from serum samples were measured colorimetrically. Malondialdehyde (MDA) in serum samples was measured as described previously (Ohkawa et al., 1979), in which MDA reacts directly with thiobarbituric acid at optimum $\mathrm{pH}$ (3.5) to produce a red color that was measured spectrophotometrically. Beta-carotene contents were measured spectrophotometrically following the method described by Suzuki and Katoh (Suzuki and Katoh, 1990). In brief, $1 \mathrm{~mL}$ of each serum sample was mixed in a brown tube with $1 \mathrm{~mL}$ of $96.5 \%$ ethanol followed by addition of $3.5 \mathrm{~mL} 98.5 \%$ hexane. Next, tubes were shaken for $10 \mathrm{~min}$ and centrifuged at $800 \times g$ for $10 \mathrm{~min}$. The supernatant was measured at $453 \mathrm{~nm}$. Concentrations of serum total protein (TP), albumin, cholesterol, and triglycerides were analyzed calorimetrically using commercial kits from Bio-Diagnostics. Progesterone $\left(\mathrm{P}_{4}\right)$ and thyroxine $\left(\mathrm{T}_{4}\right)$ concentrations were assayed using RIA and antibodycoated tube kits from Immunotech Beckman Coulter, Inc. (Prague, Czech Republic).

Data were analyzed statistically using the GLM ANOVA procedure of SPSS (Statistical Package for the 
Social Sciences; Inc., Chicago, IL, USA) v.16. A twoway ANOVA was run according to the following model: $\mathrm{Y}_{\mathrm{ijk}}=\mu+\mathrm{C}_{\mathrm{i}}+\mathrm{P}_{\mathrm{j}}+(\mathrm{C} \times \mathrm{P})_{\mathrm{ij}}+\mathrm{e}_{\mathrm{ijk}}$, in which $\mu=$ overall mean; $\mathrm{C}_{\mathrm{i}}=$ fixed effect of season condition (mild or hot); $\mathrm{P}_{\mathrm{j}}=$ fixed effect of estrous phase (I, II, III, or IV); $\mathrm{C} \times \mathrm{P}=$ interaction between the two factors; and $\mathrm{e}_{\mathrm{ijk}}=$ random error. Significances for differences in the results were checked by Duncan's test (Duncan, 1955). Differences were considered significant at $\mathrm{P} \leq 0.05$.

\section{Results}

The severity of heat stress was estimated using both ambient temperature and relative humidity, as described in Material and Methods. The obtained values indicate the following: $<22.2=$ absence of heat stress; 22.2 to $<23.3=$ moderate heat stress: 23.3 to $<25.6=$ severe heat stress; and $\geq 25.6=$ extremely severe heat stress. Temperaturehumidity index data indicated no heat stress during the mild condition, while animals were extremely heat-stressed during the hot condition. For instance, during the mild season, the average temperature and relative humidity were $22.2^{\circ} \mathrm{C}$ and $82.01 \%$, respectively, and THI was 21.74 , which indicates absence of heat stress in this period. Conversely,

Table 1 - Rectal temperature (RT) and respiratory rate (RR) of goats during estrous cycle under mild and hot Egyptian conditions

\begin{tabular}{|c|c|c|}
\hline \multirow{2}{*}{ Item } & \multicolumn{2}{|c|}{ Thermoregulatory parameter } \\
\hline & $\mathrm{RT}\left({ }^{\circ} \mathrm{C}\right)$ & RR (breaths/min) \\
\hline \multicolumn{3}{|c|}{ Condition (C) } \\
\hline Mild & $38.56 \mathrm{~B} \pm 0.046$ & $15.88 \mathrm{~B} \pm 0.11$ \\
\hline Hot & $39.75 \mathrm{~A} \pm 0.050$ & $24.86 \mathrm{~A} \pm 0.13$ \\
\hline P-value & 0.0001 & 0.0001 \\
\hline \multicolumn{3}{|c|}{ Estrus phase $(\mathrm{P})^{1}$} \\
\hline I & $39.11 \mathrm{~B} \pm 0.051$ & $22.1 \mathrm{~A} \pm 0.153$ \\
\hline II & $38.96 \mathrm{~B} \pm 0.07$ & $20.2 \mathrm{~B} \pm 0.2$ \\
\hline III & $39.07 \mathrm{~B} \pm 0.066$ & $18.43 \mathrm{C} \pm 0.15$ \\
\hline IV & $39.48 \mathrm{~A} \pm 0.06$ & $20.75 \mathrm{~B} \pm 0.15$ \\
\hline P-value & 0.0001 & 0.0001 \\
\hline \multicolumn{3}{|l|}{$\mathrm{C} \times \mathrm{P}$} \\
\hline \multicolumn{3}{|l|}{ Mild } \\
\hline I & $38.44 \mathrm{~d} \pm 0.07$ & $16.7 \mathrm{e} \pm 0.20$ \\
\hline II & $38.29 \mathrm{~d} \pm 0.09$ & $16.1 \mathrm{e} \pm 0.22$ \\
\hline III & $38.47 \mathrm{~d} \pm 0.07$ & $15.25 \mathrm{f} \pm 0.12$ \\
\hline IV & $39.03 c \pm 0.10$ & $15.45 \mathrm{f} \pm 0.14$ \\
\hline \multicolumn{3}{|l|}{ Hot } \\
\hline I & $39.77 b \pm 0.06$ & $27.5 \mathrm{a} \pm 0.24$ \\
\hline II & $39.6 \mathrm{~b} \pm 0.07$ & $24.3 c \pm 0.27$ \\
\hline III & $39.66 b \pm 0.05$ & $21.6 \mathrm{~d} \pm 0.28$ \\
\hline IV & $39.94 \mathrm{a} \pm 0.03$ & $26.01 \mathrm{~b} \pm 0.18$ \\
\hline P-value & 0.011 & 0.0001 \\
\hline
\end{tabular}

${ }^{1}$ Estrus phases: $\mathrm{I}$ = estrus; $\mathrm{II}=$ metaestrus; $\mathrm{III}$ = diestrus; $\mathrm{IV}=$ proestrus. Means with different letters (A, B, and $\mathrm{C}$ or $\mathrm{a}, \mathrm{b}$, and $\mathrm{c}$ ) in the same column are significantly different at $(\mathrm{P} \leq 0.05)$. during the summer period, average temperature, relative humidity, and THI were $34.63{ }^{\circ} \mathrm{C}, 82.44 \%$, and 33.53 , respectively. Both RT and RR had a marked significant increase $(\mathrm{P}=0.0001)$ throughout the summer compared with mild conditions. Furthermore, both parameters (RT and RR) varied considerably throughout the different phases of the animal estrous cycle $(\mathrm{P}=0.0001)$ (Table 1$)$.

All biochemical parameters tested in the current study exhibited a significant decrease in heat-stressed animals contrasted with those without heat stress. For instance, serum TP and albumin levels decreased considerably in animals under the hot summer compared with the mild season. During the estrous cycle, a decrease was recorded for TP and albumin levels, particularly in stages III and IV (Table 2). The combined effect of hot condition and estrous cycle contributed to an important decline in TP and albumin levels . Likewise, serum levels of cholesterol and triglyceride diminished significantly in goats under hot conditions $(\mathrm{P}=0.0001)$. This reduction was much more pronounced throughout the luteal phase of the estrous cycle (Table 2).

Heat-stressed goats also exhibited a marked reduction in their serum levels of antioxidants as indicated by the current data, which demonstrate some variation in the diverse stages of the estrous cycle. For example, $\beta$-carotene and total antioxidant (TA) levels had a highly significant decrease $(\mathrm{P}=0.0001)$ in animals under hot conditions and during different stages of their estrous cycle. However, the estrous cycle had no participation in the decline of $\beta$-carotene because the combined effect failed to achieve significance $(\mathrm{P}=0.637)$. This implies that a decline in the level of $\beta$-carotene could be attributed to heat stress solely, with no role of estrous cycle phase variation. Furthermore, a highly significant decrease was observed in MDA during hot conditions $(\mathrm{P}=0.0001)$ and estrous cycle, particularly in phase II. Unlike $\beta$-carotene, the decline in the MDA level could be due to the combined effect of both heat stress and estrous cycle (Table 3 ).

The levels of both progesterone and $\mathrm{T}_{4}$ were evaluated in the present study. Our data demonstrated a marked decrease in the levels of each hormone throughout the hot condition $(\mathrm{P}=0.0001)$. The levels of each hormone varied significantly during the different phases of the estrous cycle. As an example, the level of $\mathrm{P}_{4}$ fluctuated throughout the estrous cycle, showing a significant decrease during stages I, II, and III, but increased markedly in phase IV (Table 4). On the other hand, $\mathrm{T}_{4}$ showed a significant decrease during the different stages of the estrous cycle. The interaction between the effects of hot conditions and estrous cycle phases contributed to these significant variations in both $\mathrm{P}_{4}$ and $\mathrm{T}_{4}$ (Table 4). 
Table 2 - Biochemical levels of goats during estrous cycle under mild and hot Egyptian conditions

\begin{tabular}{|c|c|c|c|c|}
\hline \multirow{2}{*}{ Item } & \multicolumn{4}{|c|}{ Biochemical level } \\
\hline & Total protein $(\mathrm{gm} / \mathrm{dL})$ & Albumin $(\mathrm{gm} / \mathrm{dL})$ & Cholesterol (mg/dL) & Triglycerides $(\mathrm{mg} / \mathrm{dL})$ \\
\hline \multicolumn{5}{|c|}{ Condition (C) } \\
\hline Mild & $6.20 \mathrm{~A} \pm 0.04$ & $4.39 \mathrm{~A} \pm 0.030$ & $142.59 \mathrm{~A} \pm 0.50$ & $45.98 \mathrm{~A} \pm 0.31$ \\
\hline $\mathrm{P}$-value & 0.0001 & 0.0001 & 0.0001 & 0.0001 \\
\hline \multicolumn{5}{|c|}{ Estrus phase $(\mathrm{P})^{1}$} \\
\hline I & $6.00 \mathrm{~B} \pm 0.05$ & $3.43 \mathrm{~B} \pm 0.05$ & $136.3 \mathrm{~B} \pm 0.65$ & $39.30 \mathrm{C} \pm 0.43$ \\
\hline IV & $4.89 \mathrm{C} \pm 0.05$ & $3.05 \mathrm{C} \pm 0.5$ & $121.23 \mathrm{D} \pm 0.68$ & $36.22 \mathrm{D} \pm 0.39$ \\
\hline P-value & 0.0001 & 0.0001 & 0.0001 & 0.0001 \\
\hline \multicolumn{5}{|l|}{$\mathrm{C} \times \mathrm{P}$} \\
\hline \multicolumn{5}{|l|}{ Mild } \\
\hline I & $6.78 \mathrm{~b} \pm 0.07$ & $4.49 \mathrm{~b} \pm 0.11$ & $143.3 b \pm 0.92$ & $45.38 b \pm 0.61$ \\
\hline II & $7.20 \mathrm{a} \pm 0.05$ & $5.25 \mathrm{a} \pm 0.09$ & $156.8 \mathrm{a} \pm 1.16$ & $50.50 \mathrm{a} \pm 0.58$ \\
\hline II & $5.19 \mathrm{~d} \pm 0.031$ & $2.77 \mathrm{e} \pm 0.06$ & $138.35 \mathrm{c} \pm 1.07$ & $39.81 \mathrm{~b} \pm 0.62$ \\
\hline III & $4.40 \mathrm{e} \pm 0.10$ & $1.93 \mathrm{~g} \pm 0.05$ & $119.80 \mathrm{f} \pm 0.72$ & $35.76 c \pm 0.61$ \\
\hline IV & $4.29 \mathrm{e} \pm 0.09$ & $1.96 \mathrm{~g} \pm 0.03$ & $110.6 \mathrm{~g} \pm 0.76$ & $33.40 \mathrm{~d} \pm 0.59$ \\
\hline P-value & 0.0001 & 0.0001 & 0.001 & 0.0001 \\
\hline
\end{tabular}

${ }^{1}$ Estrus phases: $\mathrm{I}$ = estrus; $\mathrm{II}$ = metaestrus; III = diestrus; IV = proestrus.

Means with different letters (A, B, C, and D or a, b, and c) in the same column are significantly different at $(\mathrm{P} \leq 0.05)$.

Table 3 - Oxidative markers and antioxidant levels of goats during estrous cycle under mild and hot Egyptian conditions

\begin{tabular}{lccc}
\hline & \multicolumn{3}{c}{ Biochemical level } \\
\cline { 2 - 4 } Item & TA & $\begin{array}{c}\text { MDA } \\
\text { (umol/L) }\end{array}$ & $\begin{array}{c}\text { B-carotene } \\
\text { (umol } / \mathrm{L})\end{array}$ \\
\hline Condition $(\mathrm{C})$ & & & \\
Mild & $13.11 \mathrm{AL} \pm 0.15$ & $14.79 \mathrm{~A} \pm 0.20$ & $22.2 \mathrm{~A} \pm 0.22$ \\
Hot & $8.73 \mathrm{~B} \pm 0.20$ & $28.35 \mathrm{~B} \pm 0.21$ & $10.48 \mathrm{~B} \pm 0.19$ \\
P-value & 0.0001 & 0.0001 & 0.0001 \\
Estrus phases $(\mathrm{P})^{1}$ & & & \\
I & $11.58 \mathrm{~A} \pm 0.21$ & $18.53 \mathrm{~B} \pm 0.29$ & $18.15 \mathrm{~A} \pm 0.31$ \\
II & $10.80 \mathrm{AB} \pm 0.21$ & $25.32 \mathrm{~A} \pm 0.28$ & $14.80 \mathrm{C} \pm 0.32$ \\
III & $11.20 \mathrm{~A} \pm 0.21$ & $18.68 \mathrm{~B} \pm 0.31$ & $16.63 \mathrm{~B} \pm 0.31$ \\
IV & $10.10 \mathrm{~B} \pm 0.2$ & $18.55 \mathrm{~B} \pm 0.29$ & $15.78 \mathrm{BC} \pm 0.29$ \\
P-value & 0.0001 & 0.0001 & 0.0001 \\
C $\times$ P & & & \\
Mild & & & \\
I & & & \\
II & $15.25 \mathrm{a} \pm 0.40$ & $14.09 \mathrm{~d} \pm 0.18$ & $24.2 \pm 0.45$ \\
III & $11.75 \mathrm{c} \pm 0.40$ & $17.03 \mathrm{c} \pm 0.30$ & $20.4 \pm 0.56$ \\
IV & $13.45 \mathrm{~b} \pm 0.25$ & $14.15 \mathrm{~d} \pm 0.12$ & $22.7 \pm 0.53$ \\
Hot & $12.00 \mathrm{c} \pm 0.26$ & $13.89 \mathrm{~d} \pm 0.22$ & $21.5 \pm 0.54$ \\
I & & & \\
II & $9.85 \mathrm{~d} \pm 0.23$ & $22.97 \mathrm{~b} \pm 0.03$ & $12.10 \pm 0.42$ \\
III & $7.90 \mathrm{f} \pm 0.29$ & $33.60 \mathrm{a} \pm 0.49$ & $9.20 \pm 0.34$ \\
IV & $8.95 \mathrm{e} \pm 0.28$ & $23.22 \mathrm{~b} \pm 0.51$ & $10.55 \pm 0.34$ \\
P-value & $8.20 \mathrm{ef} \pm 0.24$ & $23.21 \mathrm{~b} \pm 0.48$ & $10.05 \pm 0.29$ \\
\hline TA - tota & 0.0001 & 0.0001 & 0.637 \\
\hline
\end{tabular}

TA - total antioxidant; MDA - malondialdehyde.

${ }^{1}$ Estrus phases: $\mathrm{I}$ = estrus; II = metaestrus; III = diestrus; IV = proestrus.

Means with different letters (A, B, C, and D or a, b, and c) in the same column are significantly different at $(\mathrm{P} \leq 0.05)$.
Table 4 - Progesterone and thyroxine levels of goats during estrous cycle under mild and hot Egyptian conditions

\begin{tabular}{lcc}
\hline \multirow{2}{*}{ Item } & \multicolumn{2}{c}{ Hormone } \\
\cline { 2 - 3 } Condition $(\mathrm{C})$ & Progesterone $(\mathrm{nmol} / \mathrm{L})$ & Thyroxine $(\mathrm{pmol} / \mathrm{L})$ \\
Mild & $14.73 \mathrm{~A} \pm 0.19$ & $24.48 \mathrm{~A} \pm 0.12$ \\
Hot & $10.85 \mathrm{~B} \pm 0.2$ & $15.45 \mathrm{~B} \pm 0.13$ \\
P-value & 0.0001 & 0.0001 \\
Estrus phase (P) & & \\
I & $6.82 \mathrm{C} \pm 0.27$ & $21.39 \mathrm{~A} \pm 0.16$ \\
II & $1.82 \mathrm{D} \pm 0.26$ & $18.45 \mathrm{C} \pm 0.2$ \\
III & $13.47 \mathrm{~B} \pm 0.30$ & $19.77 \mathrm{~B} \pm 0.15$ \\
IV & $29.06 \mathrm{~A} \pm 0.27$ & $20.25 \mathrm{~B} \pm 0.16$ \\
P value & 0.0001 & 0.0001 \\
C $\times$ P & & \\
Mild & & \\
I & $7.79 \mathrm{e} \pm 0.16$ & $25.89 \mathrm{a} \pm 0.20$ \\
II & $2.09 \mathrm{~g} \pm 0.10$ & $23.12 \mathrm{~b} \pm 0.31$ \\
III & $17.31 \mathrm{c} \pm 0.31$ & $23.62 \mathrm{~b} \pm 0.31$ \\
IV & $31.73 \mathrm{a} \pm 0.91$ & $25.31 \mathrm{a} \pm 0.16$ \\
Hot & & \\
I & $5.84 \mathrm{f} \pm 0.15$ & $16.89 \mathrm{c} \pm 0.11$ \\
II & $1.54 \mathrm{~g} \pm 0.04$ & $13.79 \mathrm{f} \pm 0.17$ \\
III & $9.63 \mathrm{~d} \pm 0.28$ & $15.93 \mathrm{~d} \pm 0.30$ \\
IV & $26.38 \mathrm{~b} \pm 0.32$ & $15.18 \mathrm{e} \pm 0.21$ \\
P-value & 0.0001 & 0.0001 \\
\hline
\end{tabular}

${ }^{1}$ Estrus phases: $\mathrm{I}$ = estrus; $\mathrm{II}=$ metaestrus; $\mathrm{III}$ = diestrus; $\mathrm{IV}=$ proestrus.

Means with different letters (A, B, C and D or a, b, and c) in the same column are significantly different at $(\mathrm{P} \leq 0.05)$. 


\section{Discussion}

Because of the temperature conditions in Egypt, most goats are seasonal breeders, with additional active breeding happening throughout the seasons with shorter day lengths and little to no breeding during long day lengths. In females, reproduction is controlled by the estrous cycle. This represents the time from one standing heat (estrus) to the next. This cycle normally lasts 21 days, with the particular time for the standing heat being one to a few days. This cycle continues for the lifetime of the female and is interrupted solely by season, pregnancy, or lactation.

Environmental conditions in Egypt are a combination of elements that encompass temperature, humidity, and different variables. Therefore, farm animals are raised under extreme climatic stress, especially in the summer under hot conditions. Excessive heat stress might cause hyperthermia and probably many physiological side effects. Rectal temperature and RR are perceived as essential measurements of the physiological status (Lefcourt et al., 1986) and also as ideal indicators for the assessment of stress in animals. Additionally, the increased RT and RR in goats following their exposure to hot climatic conditions demonstrate that these animals were under a stressful hot environment. Both RT and RR increased considerably during the hot season, contrasting with the mild season, which clearly indicates that this group of goats was under heat stress. This finding corroborates previous works with goats. For instance, the RT of goats was elevated with the high environmental temperature in the experiments of Minka and Ayo (2012) and Al-Samawi et al. (2014). This rise in body temperature might be ascribed to the failure of the body to reach or maintain thermal equilibrium due to insufficient heat loss (Marai et al., 2007).

Elevated RR was earlier reported as a consequence of thermal stress in goats and sheep (Okoruwa et al., 2013), which our data are in line with. The authors understood $\mathrm{RR}$ as a sensible and reliable measure of heat load and expressed that respiratory rates over 12-20 breaths/min in sheep and goats are characteristic of heat stress. Moreover, Minka and Ayo (2012) reported an incontestable rise in RR throughout the hot season and former studies suggest that in heat-stressed animals, panting is the simplest way to dissipate excess heat through evaporation (Marai et al., 2007; Al-Haidary et al., 2012). Indeed, goats are considered one amongst poorly sweating animals and tend to extend their respiratory activity to maintain their heat balance during exposure to hot conditions (Sivakumar et al., 2010).

Rectal temperature and RR demonstrated a similar trend throughout the estrus phases under the hot Egyptian conditions, compared with the mild condition. However, their trend revealed some variation during the various phases of the estrous cycle. The highest RT was in phase IV, while the lowest was in phase II, and there was a significant interaction between estrus phases and hot conditions to exert this significant amendment. The estrous cycle is related to many physiological, metabolic, and hormonal variations (Aydilek et al., 2014), leading to diverse changes according to the estrus stage. The rise in RT during phase IV compared with phase II is explained by the corpus luteum that is fully functional during this stage and the increase in blood concentration of some hormones.

Total proteins in the plasma and various intracellular compartments play an important role in the antioxidant defense system. They are considered among the main targets of free radical attack. The main function of albumin includes regulation and transport of a wide variety of substances. It likewise represses the generation of free radicals from the system (Halliwell, 1988). In the current study, a highly significant decrease in TP and albumin levels was seen in animals under hot condition (heat stress). This reduction reached $22.9 \%$ and $8.5 \%$, respectively (Table 1 ). Dangi et al. (2012) reported a decline of TP in goats under heat stress, which the present data corroborate. This decrease could also be attributed to the decrease in protein synthesis as a result of decreasing anabolic hormone secretion due to the increasing gluconeogenesis process that accompanies heat stress (El-Masry and Habeeb, 1989; Sejian and Srivastava, 2010). In addition, decreased feed intake could be another explanation for the decreasing total protein level during the hot season (Al-Haidary, 2004). However, a study by Salem et al. (1998), reported higher TP in Chios lambs and crosses with Ossimi lambs in Upper Egypt in the summer compared with the winter, which our data contradict.

Reactive oxygen metabolites are involved in numerous signaling pathways that participate mainly in the management of anabolic and catabolic processes (Dröge, 2002). There is much evidence that human serum albumin has vital antioxidant activity (Roche et al., 2008; Halliwell, 1988). A study on dairy farm cows confirmed the antioxidant role of albumin, especially near calving, when animals have a lack of vitamins and minerals (Castillo et al., 2005). Our data revealed a decrease in the levels of each TP and albumin throughout late stages of the estrous cycle under both mild and hot conditions. As opposed to our data, some previous studies demonstrated an increase in albumin and total protein levels at late stages (Yaqub et al., 2011).

Serum cholesterol and triglyceride levels of goats under hot temperatures had a noteworthy decrease that 
reached 12.68 and $22.86 \%$, respectively. The extent of this reduction of each lipid component fluctuated in various phases of the estrous cycle of the tested goats due to the combined effect of heat stress and estrous cycle. This decrease in the cholesterol/triglyceride level might be due to the diminished dry matter intake (Bobe et al., 2003), higher total body water content, and consequent dilution of blood components (hemodilution) (Habeeb et al., 1992). This decline in cholesterol/triglycerides during the hot condition could accelerate body fat catabolism and lipid mobilization (Abeni et al., 2007). A reduction in liver activity may contribute to lowering cholesterol during hot conditions (Ronchi et al., 1999). An increase in total body water may add another explanation for this reduction (Habeeb et al., 1992). It has been documented that cholesterol is a constituent of many lipoproteins. The reduction of cholesterol level during the estrous cycle (especially in the luteal phase) could be attributed to the compositional properties of low-density lipoprotein-cholesterol, which stands out amongst the most defenseless substrates for lipid peroxidation (Celi, 2010). A study by Mumford et al. (2011) likewise exhibited a marked reduction of plasma cholesterol/triglyceride levels during the luteal phase of the estrous cycle. Since cholesterol is the precursor of ovarian steroids, the declining cholesterol during the luteal phase might be a consequence of enhanced use in steroidogenesis (Rapoport et al., 1998; Piccione et al., 2009).

To evaluate the relationship between oxidative stress and estrous cycle under hot conditions, a common practice is to measure MDA as a marker for oxidative damage, TA as an antioxidant defense, and $\beta$-carotene as a micronutrient antioxidant. During the estrous cycle and hot season, TA and $\beta$-carotene levels in the plasma of female goats showed a highly significant decrease that reached around 33.3 and $52 \%$, respectively. A lower level of TA was recorded in the luteal phase compared with the other phases. Aydilek et al. (2014) found a decrease in TA in the luteal phase in cows during the estrous cycle, which the present data agree with. Oral et al. (2015) also found a reduction of TA levels during the estrous cycle of heifers. A significant interaction between seasonal variation and estrous cycle was observed for TA $(\mathrm{P}=0.0001)$. Total antioxidant activity is considered a cumulative action of all antioxidants present in serum and body fluids; this variable provides relevant information that will effectively describe the dynamic equilibrium between pro-oxidant and antioxidant agents in the plasma compartment (Cao and Prior, 1998; Ghiselli et al., 2000). Indeed, TA is viewed as a helpful tool to measure stress in ruminants (Pregel et al., 2005).
Beta-carotene is considered one amongst the most non-enzymatic, low-molecular-weight antioxidant groups and is present in the plasma in addition to extracellular and intracellular fluids. It can prevent the peroxidation process caused by oxygen radicals depending on the number of conjugated double bonds (Palozza and Krinsky, 1992). Beta-carotene can help repair tissue damage caused by free radicals (Chiu et al., 2008). A low $\beta$-carotene level was recorded in the blood of goats during their estrous cycle and under the hot condition, in the present experiment. This reduction of $\beta$-carotene level might be attributed to the impact of both estrous cycle and hot condition on goats for appropriate use of $\beta$-carotene. This biomarker can be used to measure the antioxidant capability of animals throughout exposure to heat stress and during their estrous cycle.

The MDA level indicates the lipid peroxidation process in tissues wherever the fatty acids in the cell membrane lose hydrogen molecules that increase the amount of MDA in the environment (Deveci and Güven, 2008; Celi, 2011). An abnormal state of MDA was detected in cattle with theileriosis as a result of lipid peroxidation and oxidative stress (Rezaei and Dalir-Naghadeh, 2006). In the present study, a significant increase was seen in MDA.

The estrous cycle is associated with severe metabolic and hormonal variations, particularly under hot conditions. The levels of progesterone and $\mathrm{T}_{4}$ hormones were determined during different phases of the estrous cycle of goats, in mild and hot conditions. A significant variation was recorded in the progesterone level during the estrous cycle, in which the highest amount was seen in the luteal phase (IV), while the lowest level was recorded in estrus phase II. A significant decrease in its level was reported in hot compared with mild conditions. Results of the present study agree with those of Wolfenson et al. (2002), who reported a significantly higher serum progesterone level in the winter compared with summer in Holstein cows during estrus phases.

It has also been reported that a higher progesterone concentration during the mid-luteal phase in the winter compared with the summer is due to the dominant influence on oviduct uterus, pituitary, and hypothalamus (Johnson, 1987). However, no significant effect was seen on $P_{4}$ concentrations under hot conditions (Wilson et al., 1998). A lower level of $\mathrm{T}_{4}$ was recorded in hot compared with mild conditions. Decreasing the $\mathrm{T}_{4}$ hormone might be an alternative to reduce the metabolic rate and heat production during exposure to heat stress (West, 1999).

Free radicals serve as substrates for the thyroid hormone; therefore, production of additional free radicals as a result of 
heat stress might have an effect on the amount of hormone (Deshpande et al., 2002). Moreover, 5 ' monodeiodinase, an enzyme that converts $T_{3}$ to $T_{4}$, is affected by free radicals, under heat stress (Brzezinska-Slebodzinska, 2001).

\section{Conclusions}

Egyptian conditions have detrimental effects on some antioxidant agents and some biochemical parameters during the estrous cycle of goats. Understanding the effect of the heat-stress mechanism could contribute to the development of new markers to predict heat stress in goats.

\section{Acknowledgments}

We thank all staff members of the goat farm experimental animal unit, for their technical support. Especial thanks to Dr. Hassan Farghally and Dr. Hussein El-Zaher, for introducing all the facilities during the whole experimental period.

\section{References}

Abeni, F.; Calamari, L. and Stefanini, L. 2007. Metabolic conditions of lactating Frisian cows during the hot season in the Po Valley. 1. Blood indicators of heat stress. International Journal of Biometrology 52:87-96.

Al-Haidary, A. A. 2004. Physiological responses of Naimy sheep to heat stress challenge under semi-arid environment. International Journal of Agriculture and Biology 2:307-309.

Al-Haidary, A.; Aljumaah, R. S.; Alshaikh, M. A.; Abdoun, K. A.; Samara, E. M.; Okab, A. B. and Alfuraiji, M. M. 2012. Thermoregulatory and physiological responses of Najdi sheep exposed to environmental heat load prevailing in Saudi Arabia. Pakestan Veterinary Journal 32:515-519.

Al-Samawi, K. A.; Al-Hassan, M. J. and Swelum, A. A. 2014. Thermoregulation of female aardi goats exposed to environmental heat stress in Saudi Arabia. Indian Journal of Animal Research 48:344-349.

Aydilek, N.; Varişli, Ö.; Selek, Ş.; Korkmaz, Ö.; Atli, M. O. and Taşkin, A. 2014. The effect of estrous cycle on oxidant and antioxidant parameters in dairy cows. Kafkas Üniversitesi Veteriner Fakültesi Dergisi 20:703-709.

Bernabucci, U.; Ronchi, B.; Lacetera, N. and Nardone, A. 2002. Markers of oxidative status in plasma and erythrocytes of transition dairy cows during hot season. Journal of Dairy Science 85:2173-2179.

Bobe, G.; Ametaj, N. B.; Young, J. W. and Beitz, D. C. 2003. Effects of exogenous glucagon on lipids in lipoproteins and liver of lactating dairy cows. Journal of Dairy Science 86:2895-2903.

Browne, R. W.; Bloom, M. S.; Schisterman, E. F.; Hovey, K.; Trevisan, M.; Wu, C.; Liu, A. and Wactawski-Wende, J. 2008. Analytical and biological variation of biomarkers of oxidative stress during the menstrual cycle. Biomarkers 13:160-183.

Brzezinska-Slebodzinska, E. 2001. Fever induced oxidative stress: the effect on thyroid status and the 5'-monodeiodinase activity, protective role of selenium and vitamin E. Journal of Physiology and Pharmacology 52:275-284.
Castillo, C.; Hernandez, J.; Bravo, A.; Lopez-Alonso, M.; Pereira, V. and Benedito, J. L. 2005. Oxidative status during late pregnancy and early lactation in dairy cows. The Veterinary Journal 169:286-292.

Cao, G. and Prior, R. L. 1998. Comparison of different analytical methods for assessing total antioxidant capacity of human serum. Clinical Chemistry 44:1309-1315.

Celi, P. 2010. The role of oxidative stress in small ruminants' health and production. Revista Brasileira de Zootecnia 39:348-363.

Celi, P. 2011. Biomarkers of oxidative stress in ruminant medicine. Immunopharmacology and Immunotoxicology 33:233-240.

Celi, P.; Merlo, M.; Barbato, O. and Gabai, G. 2012. Relationship between oxidative stress and the success of artificial insemination in dairy cows in a pasture-based system. Veterinary Journal 193:498-502.

Chiu, H. J.; Fischman, D. A. and Hammerling, U. 2008. Vitamin A depletion causes oxidative stress, mitochondrial dysfunction, and PARP-1-dependent energy deprivation. The FASEB Journal 22:3878-3887.

Dangi, S. S.; Gupta, M.; Maurya, D.; Yadav, V. P.; Panda, R. P.; Singh, G.; Mohan, N. H.; Bhure, S. K.; Das, B. C.; Bag, S.; Mahapatra, R.; Taru Sharma, G. and Sarkar, M. 2012. Expression profile of HSP genes during different seasons in goats (Capra hircus). Tropical Animal Health and Production 44:1905-1912.

Deshpande, U. R.; Joseph, L. J.; Patwardhan, U. N. and Samuel, A. M. 2002. Effect of antioxidants (vitamin C, E and turmeric extract) on methimazole induced hypothyroidism in rats. Indian Journal of Experimental Biology 40:735-738.

Deveci, A. H. and Güven, A. 2008. Mastitisli ineklerde kan MDA ve GSH düzeylerinin araştırılması. Kafkas Üniversitesi Veteriner Fakültesi Dergisi 14:63-66.

Dröge, W. 2002. Free radicals in the physiological control of cell function. Physiological Reviews 82:47-95.

Duncan, D. B. 1955. Multiple range and multiple F tests. Biometrics 11:1-42.

El-Masry, K. A. and Habeeb, A. A. 1989. Thyroid function in lactating Friesian cows and water buffaloes under winter and summer. In: Proceedings of the 3rd Egyptian British Conference on Animal, Fish and Poultry Production 2:613-620.

Ghiselli, A.; Serafini, M.; Natella, F. and Scaccini, C. 2000. Total antioxidant capacity as a tool to assess redox status: critical view and experimental data. Free Radical Biology \& Medicine 29:1106-1114

Habeeb, A. A.; Marai, F. M. and Kamal, T. H. 1992. Heat stress. p.27-47. In: Farm animals and the environment. Phillips, C. and Piggins, D., eds. CAB International, Wallingford, UK.

Halliwell, B. 1988. Albumin- An important extracellular antioxidant? Biochemical Pharmacology 37:569-571.

Hooda, O. K. and Upadhyay, R. C. 2014. Physiological responses, growth rate and blood metabolites under feed restriction and thermal exposure in kids. Journal of Stress Physiology and Biochemistry 10:214-227.

Jarosz, S. J.; Deans, R. J. and Dukelow, W. R. 1971. The reproductive cycle of the African Pygmy and Toggenburg goat. Journal of Reproduction and Fertility 24:119-123.

Johnson, H. D. 1987. Bioclimates and livestock. Bioclimatology and the adaptation of livestock. World Animal Science (Johnson, H. D. ed.), New York.

Jordan, E. R. 2003. Effects of heat stress on reproduction. Journal Dairy Science 86:E104-E114.

Koracevic, D.; Koracevic, G.; Djordjevic, V.; Andrejevic, S. and Cosic, V. 2001. Method for the measurement of antioxidant activity in human fluids. Journal of Clinical Pathology 54:356-361. 
Lefcourt, A. M.; Kahl, S. and Akers, M. R. 1986. Correlation of indexes of stress with intensity of electrical shock for cows. Journal of Dairy Science 69:833-842.

LPHSI - Livestock and Poultry Heat Stress Indices. 1990. Agriculture engineering technology guide. Clemson Univeristy, Clemson, SC, USA.

Marai, I. F. M.; El-Darawany, A. A.; Fadiel, A. and Abdel-Hafez, M. A. M. 2007. Physiological traits as affected by heat stress in sheep: a review. Small Ruminant Research 71:1-12.

Miller, J. K.; Brzezinska-Slebodzinska, E. and Madsen, F. C. 1993. Oxidative stress, antioxidants and animal function. Journal of Dairy Science 76:2812-2823.

Minka, N. S. and Ayo, J. O. 2012. Assessment of thermal load on transported goats administered with ascorbic acid during the hot-dry conditions. International Journal of Biometeorology 56:333-341.

Monty, D. W. and Wolff, L. K. 1974. Summer heat stress and reduced fertility in Holstein-Friesian cows in Arizona. American Journal of Veterinary Research 35:1495-1500.

Mumford, S. L.; Schisterman, E. F.; Siega-Riz, A. M.; Gaskins, A. J.; Wactawski-Wende, J. and VanderWeele, T. J. 2011. Effect of dietary fiber intake on lipoprotein cholesterol levels independent of estradiol in healthy premenopausal women. American Journal of Epidemiology 173:145-156.

NRC - National Research Council. 2007. Nutrient requirements of small ruminants sheep, goats, cervids, and New World camelids. National Academy Press, Washington, DC.

Ohkawa, H.; Ohishi, N. and Yagi, K. 1979. Assay for lipid peroxides in animal tissues by thiobarbituric acid reaction. Analytical Biochemistry 95:351-358.

Okoruwa, M. I.; Adewumi, M. K. and Igene, F. U. 2013. Thermophysiological responses of West African dwarf (WAD) bucks fed Pennisetum purpureum and unripe plantain peels. Nigeria Journal of Animal Science 15:168-178.

Oral, H.; Öğün, M.; Kuru, M. and Kaya, S. 2015. Evaluation of certain oxidative stress parameters in heifers that were administered short term PRID. Kafkas Üniversitesi Veteriner Fakültesi Dergisi 21:569-573.

Palozza, P. and Krinsky, N. I. 1992. Antioxidant effects of carotenoids in vivo and in vitro: an overview. Methods of Enzymology 20:213-403.

Piccione, G.; Caola, G.; Giannetto, C.; Grasso, F.; Calanni Runzo, S.; Zumbo, A. and Pennisi, P. 2009. Selected biochemical serum parameters in ewes during pregnancy post-parturition, lactation and dry period. Animal Science 27:321-330.

Pregel, P.; Bollo, E.; Cannizzo, F. T.; Biolatti, B.; Contato, E. and Biolatti, P. G. 2005. Antioxidant capacity as a reliable marker of stress in dairy calves transported by road. Veterinary Record 156:53-54.

Rapoport, R.; Sklan, D.; Wolfenson, D.; Shaham-Albalancy, A. and Hanukoglu, I. 1998. Antioxidant capacity is correlated with steroidogenic statusof the corpus luteum during the bovine estrous cycle. Biochimica et Biophysica Acta 1380:133-140.

Rezaei, A. S. and Dalir-Naghadeh, B. 2006. Evaluation of antioxidant status and oxidative stress in cattle naturally infected with Theileria annulata. Veterinary Parasitology 142:179-186.

Roche, M.; Rondeau, P.; Singh, N. R.; Tarnus, E. and Bourdon, E. 2008. The antioxidant properties of serum albumin. FEBS Letters 582:1783-1787.

Ronchi, B.; Bernabucci, U.; Lacetera, N.; Verini Supplizi, A. and Nardone, A. 1999. Distinct and common effects of heat stress and restricted feeding on metabolic status of Holstein heifers. Zootecnica e Nutrizione Animale 25:11-20.

Salem, N.; Faúndez, V.; Horng, J. T. and Kelly, R. B. 1998. A v-snare participates in synaptic vesicle formation mediated by the AP3 adaptor complex. Nature Neuroscience 1:551-556.

Sejian, V. and Srivastava, R. S. 2010. Effect of melatonin on adrenal cortical functions of Indian goats under thermal stress. Veterinary Medicine International ID 348919, 6.

Sivakumar, A. V. N.; Singh, G. and Varshney, V. P. 2010. Antioxidants supplementation on acid base balance during heat stress in goats. Asian-Australian Journal of Animal Sciences 23:1462-1468.

Sordillo, L. M. and Aitken, S. L. 2009. Impact of oxidative stress on the health and immune function of dairy cattle. Veterinary Immunology Immunopathology 128:104-109.

Suzuki, J. P. and Katoh, N. A. 1990. A simple and cheap method for measuring serum vitamin A in cattle using only spectrophotometer. Japanese Journal of Veterinary Science 52:1281-1283.

Trevisan, M.; Browne, R.; Ram, M.; Muti, P.; Freudenheim, J.; Carosella, A. M. and Armstrong, D. 2001. Correlates of markers of oxidative status in the general population. American Journal of Epidemiology 154:348-356.

West, J. W. 1999. Nutritional strategies for managing the heat- stressed dairy cows. Journal of Animal Science 77:21-35.

Wilson S. J.; Marion, R. S.; Spain, J. N.; Spiers, D. E.; Keisler, D. H. and Lucy, M. C. 1998. Effects of controled heat stress on ovarian function of dairy cattle. 1. Lactating cows. Journal of Dairy Science 81:2124-2131.

Wolff, L. K. and Monty, D. E. 1974. Physiologic response to intense summer heat and its effect on the estrous cycle of non-lactating and lactating Holstein-Friesian cows in Arizona. American Journal of Veterinary Research 35:187-192.

Wolfenson, D.; Sonego, H.; Bloch, A.; Shaham-Albalancy, A.; Kaim, M.; Folman, Y. and Meidan, R. 2002. Seasonal differences in progesterone production by luteinized bovine thecal and granulosa cells. Domestic Animal Endocrinology 22:81-90.

Yaqub, L. S.; Ayo, J. O.; Rekwot, P. I.; Oyeanusi, B. I.; Kawu, M. U.; Ambali, S. F.; Shittu, M. and Abdullahi, A. 2011. Changes in serum proteins and urea during the oestrous cycle in Red Sokoto goats. Advances in Applied Science Research 2:197-205. 